\title{
Identification of low penetrance alleles for lung cancer: The GEnetic Lung CAncer Predisposition Study (GELCAPS) Tim Eisen ${ }^{1}$, Athena Matakidou², Richard Houlston*2 for the GELCAPS Consortium $^{3}$
} \author{
Research, Sutton, Surrey, SM2 5NG, UK and ${ }^{3}$ List of collaborators available on request \\ Email: Tim Eisen - tgqe2@cam.ac.uk; Athena Matakidou - athena.matakidou@bartsandthelondon.nhs.uk; \\ Richard Houlston* - richard.houlston@icr.ac.uk; the GELCAPS Consortium - richard.houlston@icr.ac.uk \\ * Corresponding author
}

Address: ${ }^{1}$ Department of Medical Oncology, University of Cambridge, Cambridge CB2 2RE, UK, 2 Section of Cancer Genetics, Institute of Cancer

Published: 20 August 2008

BMC Cancer 2008, 8:244 doi:10.1 186/147/-2407-8-244
Received: 18 December 2007

Accepted: 20 August 2008

This article is available from: http://www.biomedcentral.com/I47I-2407/8/244

(C) 2008 Eisen et al; licensee BioMed Central Ltd.

This is an Open Access article distributed under the terms of the Creative Commons Attribution License (http://creativecommons.org/licenses/by/2.0), which permits unrestricted use, distribution, and reproduction in any medium, provided the original work is properly cited.

\begin{abstract}
Background: Part of the inherited risk to lung cancer is likely to include common, low risk alleles. The identification of this class of susceptibility is contingent on association-based analyses. We established GEnetic Lung CAncer Predisposition Study (GELCAPS) to collect DNA and clinicopathological data from a large series of cases and a series of spouse/partner controls, thereby generating a key resource for the identification of low risk alleles.
\end{abstract}

Methods: GELCAPS was one of the first genetic epidemiological trials in the UK to be adopted by the National Cancer Research Network (NCRN) onto its portfolio with the participation of over 100 oncology departments specialising in the management of lung cancer.

Results: Samples from over 5,000 independent lung cancer cases and 2,000 controls have so far been assembled through GELCAPS.

Conclusion: GELCAPS represents one of the largest datasets of its type in the world capable of informing on the contribution of low penetrance alleles to the development of lung cancer and the influence of genetic variation on outcome. In addition our experience in developing the GELCAPS serves to illustrate how large DNA biobanks for genetic analyses can be rapidly generated within the UK using the NCRN.

\section{Background}

Lung cancer is a major cause of cancer mortality worldwide [1]. In the United Kingdom, it accounts for more than 33,000 cancer deaths each year (Cancer Research $\mathrm{UK})$. The disease is frequently cited as a malignancy solely attributable to environmental exposure, principally tobacco smoking. It has, however, long been postulated that individuals may differ in their susceptibility and there is strong evidence from epidemiological studies for a familial risk [reviewed in [2]]. Direct evidence for a genetic predisposition is provided by the increased risk of lung cancer associated with a number of rare Mendelian cancer syndromes, such as in carriers of germline TP53 [3] and $R B$ $[4,5]$ mutations, as well as in patients with Bloom's [6] and Werner's [7] syndromes.

The two major types of lung cancer, non-small cell lung cancer (NSCLC), and small cell lung cancer (SCLC) 
account for $75 \%$ and $25 \%$ of cases respectively. Although the histological features are different between these (reflected in differences in patterns of gene expression), there are similarities in the spectrum of underlying somatic genetic alterations suggesting commonality in pathogenesis. Moreover, the observation that the familial risks are not subtype dependent [8-13] and that histological concordance between affected family members is poor [9] is consistent with the hypothesis of a "generic" inherited susceptibility to lung cancer.

The genetic basis of inherited susceptibility to lung cancer outside the context of the rare Mendelian cancer predisposition syndromes is at present undefined, but a model in which major gene loci account for the excess familial risk seems unlikely. One hypothesis about the allelic architecture of susceptibility proposes that part of the genetic risk is caused by disease loci, which include common, low penetrance alleles. This "common-disease common-variant" hypothesis implies that conducting association analyses based on scans of Single Nucleotide Polymorphisms (SNPs) should be a powerful strategy for identifying lowpenetrance variants $[14,15]$.

Previous studies aimed at identifying low penetrance alleles for lung cancer susceptibility have largely been based on a candidate gene approach formulated on preconceptions as to the role of specific genes in the development of the disease. Perhaps not surprisingly most studies have to date only evaluated a restricted number of polymorphisms, primarily in genes implicated in the metabolism of tobacco-associated carcinogens and the protection of DNA from carcinogen-induced damage. However, without a clear understanding of the biology of lung cancer predisposition the definition of suitable genes for the disease is inherently problematic making an unbiased approach to loci selection highly desirable.

Despite much research, few definitive low penetrance susceptibility alleles for lung cancer have been to date unequivocally been identified through candidate-based association studies. As with many other diseases, positive associations have been reported for various polymorphisms of genes such as GSTT1 [16], GSTM1 [17], ERCC2 [18], CYP1A1 [19], and TP53 [20] from small studies, but few of the initial positive results have been replicated in subsequent studies. The inherent statistical uncertainty of case-control studies involving just a few hundred cases and controls seriously limits the power of such studies to reliably identify genetic variants conferring modest but potentially important risks.

In addition to genetic variation affecting the risk of developing cancer it is increasingly being recognised that genetic variation, not necessarily in the same genes, may also affect clinical outcome. As with case-control association studies aiming to identify novel susceptibility alleles the same issues of study power pertain to the search for prognostic markers and such studies are again contingent on access to large case-series.

Following the sequencing of the human genome, largescale harvests of SNPs have been conducted and $>10$ million documented. Patterns of linkage disequilibrium (LD) between SNPs have been characterised allowing subsets of SNPs (tagging SNPs) to be selected that capture a large proportion of the common sequence variation in the human genome. This coupled with the advent of highly efficient analytical platforms allow whole genome-wide studies (GWAS) for disease associations to be conducted cost effectively. The relationship between patients' genotype and risk of lung cancer is now open for exploration.

The identification of genes associated with cancer predisposition and determination of their contribution to disease incidence are contingent on having DNA samples from large, systematic series of cancer patients. The resulting genetic epidemiological data provides the information on which to base the identification, counselling and management of at-risk individuals. The National Cancer Research Network (NCRN) was established to provide support for clinical cancer research in England and is one of the most substantial and constructive developments in the area of cancer research to be made in recent years in the United Kingdom. In England, serving a population of 50 million people, the NCRN is made up of 34 geographically distinct Networks covering the entire country. Within each Network there are clinical research support staff and infrastructure to promote accrual of patients into trials and studies, and the collection of high quality clinico-pathological data and appropriate biological samples. Hence the NCRN presents a major scientific initiative not only in the field of clinical trials but also in the field of genetic epidemiology.

To create a resource for identifying low penetrance alleles for lung cancer we established GELCAPS (GEnetic Lung CAncer Predisposition Study) in March 1999 to collect DNA and clinico-pathological data from a large series of lung cancer cases. Within 5-years of setting up the initiative by linkage with the NCRN it has been possible to create a world-class resource of biological and clinicopathological data from over 5,000 individuals with lung cancer.

\section{Methods/Design Eligibility criteria}

All patients diagnosed with lung cancer between March 1999 and July 2004 were eligible for the study. To ensure that data and samples were collected from bona fide lung 
cancer cases and avoid issues of bias from survivorship only incident cases with histologically or cytologically (only if not adenocarcinoma) confirmed primary disease were ascertained. Partners of recruited lung cancer patients with no personal history of cancer were recruited as controls.

\section{Procedural outline}

A standardised questionnaire was used to collect basic demographic characteristics-sex, date of birth, ethnic group (White, Black-Caribbean, Black-African, Blackother, Indian, Pakistani, Chinese, Other), country of birth, current area of residence - in addition to details on active and past smoking history (including type of tobacco product, amount smoked, age at first cigarette and age at any major change of smoking habits), exposure to asbestos, occupational history, and personal past medical history. All questionnaires were self-administered and no surrogate responders were used. An open question was used to obtain information on family history of cancer involving first-degree relatives. A positive history of lung cancer was only assigned when detailed information was provided identifying the family member affected by lung cancer. The referring clinician using a standard registration form supplied clinico-pathological details (type of lung cancer, stage at presentation) of patients.

Coupled with patient recruitment their spouses/partners who had no known past or current history of malignancy were invited to participate for the purposes of contributing to the generation of a control series. For these individuals details of sex, date of birth, ethnic group, place of birth, current area of residence and smoking history were collected through a self-administered questionnaire. 10$20 \mathrm{ml}$ EDTA-venous blood samples were collected from all participants. Consent forms, questionnaires, registration forms and blood samples were returned to the Institute of Cancer Research (ICR) by mail. Blood samples collected were stored at $-80^{\circ} \mathrm{C}$ prior to DNA extraction and quantification.

It is our intention to collect outcome data on all cases entered into GELCAPS. In the first stage of this process subsets of participating centers were asked to provide the clinical details on the outcome of the recruited lung cancer patients. Records were requested based on their date of accrual, with those accrued at the beginning of the study being requested first. A standard proforma was used to collect information on diagnosis, stage, treatment and survival. Fully informed consent was obtained from all patients alive at the time of outcome data collection. Outcome forms were returned to the ICR by mail and details were stored electronically.

\section{Statistical considerations}

The primary aim of establishing GELCAPS was to generate a DNA resource of lung cancer patients sufficiently large to robustly identify low penetrance alleles by association studies of genetic polymorphisms. From the outset we envisaged that at some juncture such searches would be conducted on a genome-wide basis. It is well recognised that as such studies involve typing a vast number of markers, a large number of false positive associations will inevitably be generated and only a small number of markers will be truly associated with disease susceptibility. Hence associations need to attain a high level of statistical significance to be established beyond reasonable doubt and significance levels of $\sim 10^{-7}$ have been proposed as being appropriate [14]. The original target of GELCAPS was to assemble a series to include $~ 2,000$ cases. This figure had been arrived upon on the basis of upon contemporaneous views of the probable impact of common alleles on disease risk. During development of GELCAPS studies of other common diseases indicated that common disease alleles are likely to be associated with risks typically in the range of 1.1-1.5. To identify alleles conferring such risks is contingent on sample sets twice that of our original target and we therefore revised our target accordingly in order to have $\sim 80 \%$ power to identify an association between SNP genotype and risk.

\section{Ethical considerations}

In generating DNA registries such as GELCAPS ethical considerations are central to study design. One of the particular strengths of studies such as GELCAPS is that once constructed the DNA database can be probed repeatedly for different existing and newly identified candidate risk factor genes. It is not feasible to contact all study entrants to seek further written consent for specific test therefore, the information sheet and study discussion was centred on the general concept of 'genetic analyses'. As these investigations were to be solely for research to find new gene(s) predisposing to cancer it was implicit that no individual results will be conveyed to persons. In publications of findings no study entrant would be identifiable. As with all studies of this nature we clearly stated that if a study entrant wished to withdraw their DNA sample and all information held on them would be destroyed. To ensure confidentiality data is held under secure conditions at the ICR Institute of Cancer Research and information held on study entrants will not be divulged to any person or agency without the prior written agreement of the study entrant.

All clinical information and biological samples were obtained only after fully informed consent was obtained from participating individuals, and in accordance with the tenets of the Declaration of Helsinki. Ethical approval for the study was obtained from the London Multi-Centre 
Research Ethics Committee (MREC/98/2/67) and local ethical committees. Personal information was stored in accordance with the Data Protection Act (1998).

\section{Extraction of DNA, storage and quality assurance}

DNA was extracted from EDTA blood samples using either a standard salt extraction procedure or using the Chemagen system (Chemagen Biopolymer-Technologie AG, Arnold-Somerrfield-Ring 2, 5499 Baeswelder, Germany, Picogreen quantified (Quant-it, Invitrogen, Paisely, UK) and normalised to $100 \mathrm{ug} / \mathrm{ul}$ in TE buffer. DNAs stocks are being stored in Eppendorf tubes (Barkhausenwe 122339 Hamburg, Germany) at $-80^{\circ} \mathrm{C}$. To avoid subjecting stock DNAs being to repeated thawing and freezing we have generated a series of "master" 96 deep well plates of samples from which DNAs can be readily robotically abstracted for genotyping studies. Fidelity of DNA is being constantly evaluated by monitoring performance in the different genotyping platforms.

\section{Results}

After securing ethical permissions at a national level through the Multi Research Ethics Committee we started recruitment to GELCAPS in March 1999. Ascertainment of cases was restricted to 28 centres and accrual was maximally 10-20 patients per month. After GELCAPS was incorporated into the NCRN (National Cancer Research Network) portfolio in March 2002 it was subsequently rolled out across England after individual centers had obtained local ethical permissions. Adoption by the NCRN was associated with a significant increase in patient and control accrual (Figure 1). Eventually 140 oncology centers (Figure 2) became active participants in GELCAPS with patient ascertainment averaging $\sim 100$ cases per

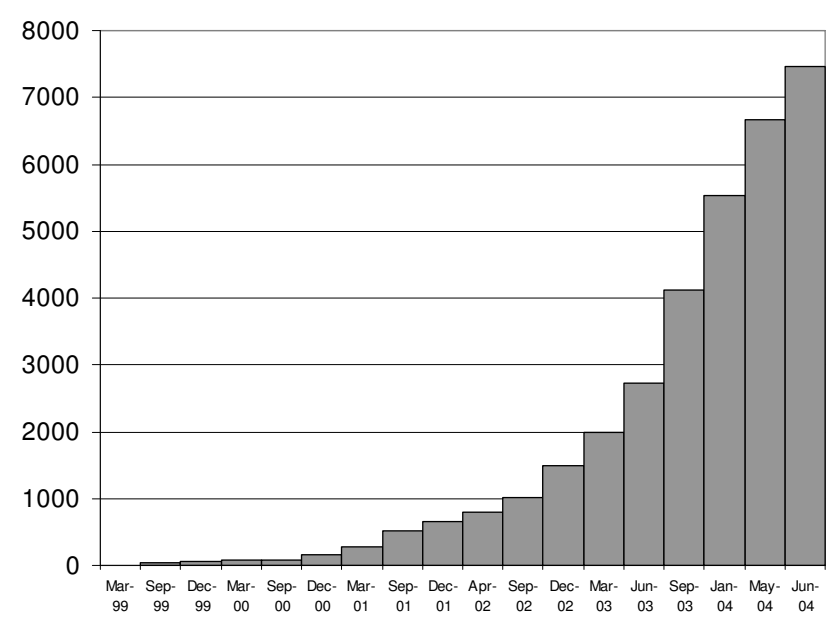

Figure I

Accrual of cases and controls to GELCAPS. month. The remit and operational procedure by which patients are accrued to NCRN adopted studies does not allow collection of compliance data within each participating center. However, we estimate based on our intimate knowledge of the clinical activities of three centers that patient accrual to GELCAPS is $~ 70 \%$ of those invited to participate.

The original target of GELCAPS was to assemble a series of 2,000 lung cancer cases. Given the efficiency by which samples were being accrued following adoption of GELCAPS by the NCRN a new target of at least 4,000 cases was deemed to be eminently feasible within the time frame for which funding had been secured.

We terminated accrual to GELCAPS in July 2004 by which time samples from 5,269 cases with primary lung cancer and 2,094 controls had been recruited. The majority of cases were male $(64 \%)$ reflecting the sex preponderance of disease. Whilst the mean age of controls was comparable to cases $(62.9$ years, $\mathrm{SD}=10.6)$ not surprisingly $69 \%$ were female (Table 1). Similarly, the prevalence of smoking was significantly higher amongst cases compared to controls. A high proportion of the cases ascertained had been diagnosed with lung cancer at a young age (Table 1); specifically 1,617 ( $31 \%)$ of the cases were aged less than 60 years old at diagnosis, compared with $<10 \%$ in the general population. The frequency of the various forms of lung cancer was, however, in keeping with that observed in UK general population - 23\% being affected with SCLC and $73 \%$ with NSCLC (Table 1).

To date we have acquired follow up data on 1,187 patients; specifically, information on the staging, management and clinical outcome permitting comparison patients randomly drawn from the general population. Stage at presentation for each of the different subtypes of lung cancer was similar to that observed in the general population; specifically, for patients with SCLC, somewhat less than half (43\%) presented with limited disease and of the patients with NSCLC, 13\% had stage I, 15\% had stage II, $43 \%$ had stage III, and $29 \%$ had stage IV disease. The majority of patients with limited stage SCLC had been treated with a combination of radical radiotherapy and chemotherapy, whilst all patients received chemotherapy. The main treatment modality for SCLC patients with extensive disease was chemotherapy. Patients with early stage NSCLC (stage I and II disease) were mainly treated with surgical resection of the primary tumor whilst about one third received chemotherapy and radical radiotherapy. The mainstay treatment modality of patients with stage III and IV NSCLC was chemotherapy. Overall the median survival time (MST) for the subset of 1,187 GELCAPS patients was 18.6 months. Prognosis was significantly correlated with stage at presentation, with those 


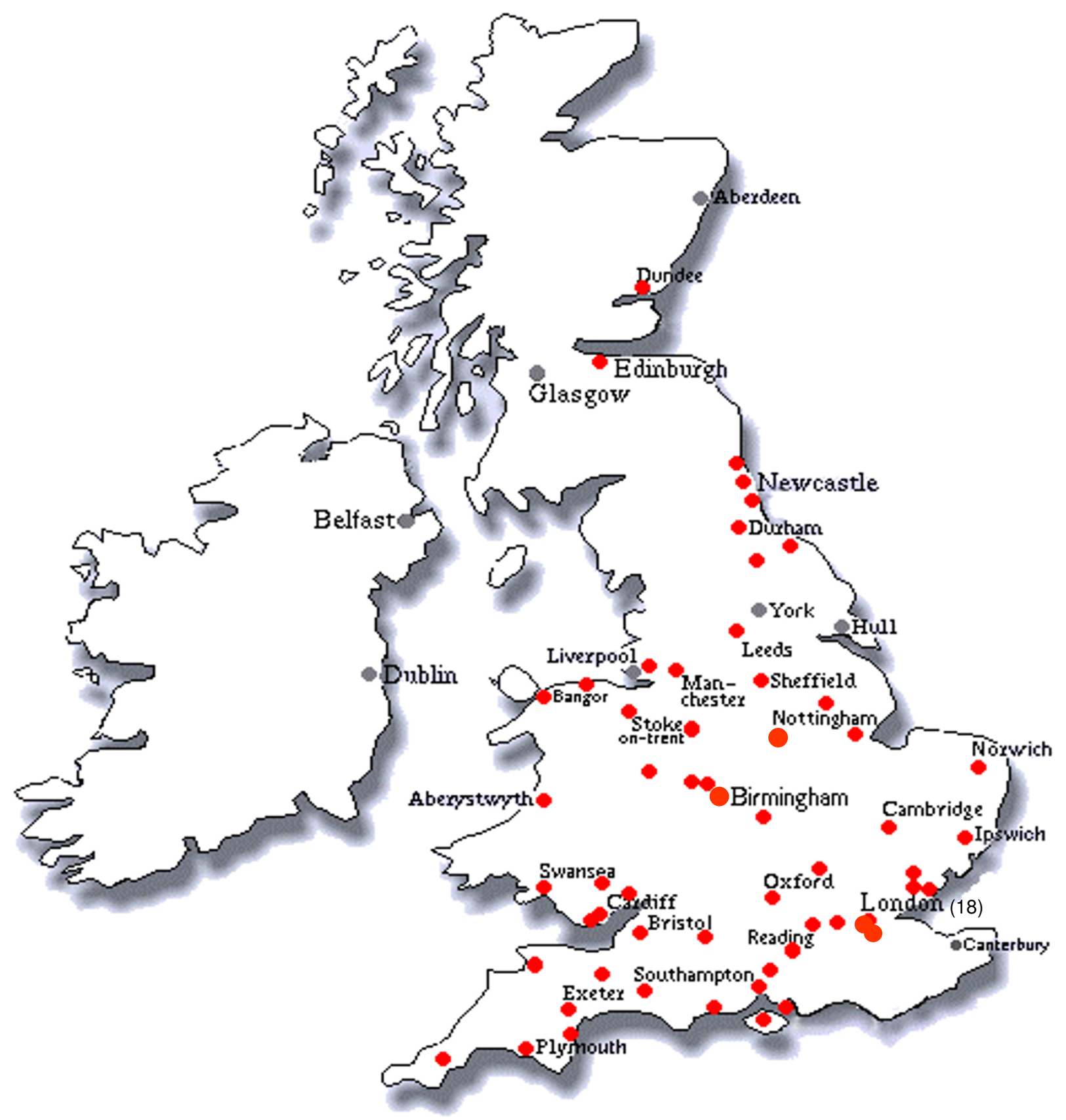

Figure 2

Centres in the UK recruiting to GELCAPS after NCRN adoption.

presenting early have a far better survival (Figure 3). Patients with SCLC had a MST of 26.0 and 10.5 months if diagnosed with limited and extensive disease respectively. For those with NSCLC, MSTs ranged from 12.1 months for stage IV patients to 32.3 months for stage I disease.

\section{Discussion}

Recent data from GWASs of breast $[21,22]$, prostate [2327] and colorectal (CRC) cancer [28-31] provides strong evidence for the involvement of common disease-causing alleles and suggests that a relatively large number of genes 
Table I: Characteristics of lung cancer patients recruited to GELCAPS

\begin{tabular}{|c|c|c|}
\hline & Cases & Controls \\
\hline Total & 5,269 & 2,094 \\
\hline Gender (Male: Female) & $3,382(64.2 \%)$ & $645(30.8 \%)$ \\
\hline Age at diagnosis (years) & $887(35.8 \%)$ & $446(69.1 \%)$ \\
\hline$<40$ & $53(1.0 \%)$ & $64(3.1 \%)$ \\
\hline $40-49$ & $302(5.7 \%)$ & $166(7.9 \%)$ \\
\hline $50-59$ & $\mathrm{I}, \mathrm{I} 46(21.7 \%)$ & $514(24.5 \%)$ \\
\hline $60-69$ & $1,868(35.4 \%)$ & $756(36.1 \%)$ \\
\hline 70-79 & $1,590(30.1 \%)$ & $510(24.4 \%)$ \\
\hline $80+$ & $310(5.9 \%)$ & $84(4.0 \%)$ \\
\hline Mean (SD) & $65.1(10.0)$ & $62.9(10.6)$ \\
\hline \multicolumn{3}{|l|}{ Ethnicity } \\
\hline Arabic & $3(0.05 \%)$ & I (0.05\%) \\
\hline Asian & $7(0.13 \%)$ & $6(0.29 \%)$ \\
\hline Bangladeshi & $\mathrm{I}(0.01 \%)$ & 0 \\
\hline Black-African & $4(0.08 \%)$ & I $(0.05 \%)$ \\
\hline Black-Caribbean & $31(0.59 \%)$ & $8(0.38 \%)$ \\
\hline Black-Other & I (0.01\%) & 0 \\
\hline Indian & $16(0.30 \%)$ & $4(0.19 \%)$ \\
\hline Jewish-Ashkenazi & $12(0.22 \%)$ & $6(0.29 \%)$ \\
\hline Pakistani & $8(0.15 \%)$ & 0 \\
\hline White & $5,065(96.1 \%)$ & $1,947(93.0 \%)$ \\
\hline Other/not specified & $82(1.6 \%)$ & $121(5.8 \%)$ \\
\hline Reported asbestos exposure & $807(15.2 \%)$ & $125(6.0 \%)$ \\
\hline Family history of lung cancer & $750(14.2 \%)$ & $212(10.1 \%)$ \\
\hline \multicolumn{3}{|l|}{ Smoking habits } \\
\hline Never-smokers & $307(5.8 \%)$ & $7 \mid 8(34 \%)$ \\
\hline \multicolumn{3}{|l|}{ All smokers } \\
\hline Age first started smoking (SD) & $16.5(4.0)$ & $17.9(4.8 \%)$ \\
\hline Pack years in Smokers (SD) & $47.2(30.6)$ & $30.4(22.1 \%)$ \\
\hline \multicolumn{3}{|l|}{ Histology of cancer } \\
\hline Small cell (SCLC) & $1,193(22.6 \%)$ & \\
\hline Non-small cell (NSCLC) & $3,815(72.4 \%)$ & \\
\hline Squamous & $1,905(49.9 \%)$ & \\
\hline Adenocarcinoma (including variants) & $1,110(29.1 \%)$ & \\
\hline Large cell & $10(0.3 \%)$ & \\
\hline Brochoalveolar & $44(1.2 \%)$ & \\
\hline Adenosquamous & II (0.3\%) & \\
\hline Neuroendocrine & $20(0.5 \%)$ & \\
\hline NSCLC unspecified & $715(18.7 \%)$ & \\
\hline Sarcoma & $5(0.1 \%)$ & \\
\hline Unclassified primary & $256(4.9 \%)$ & \\
\hline \multicolumn{3}{|l|}{ Tumour stage at presentation, by histology } \\
\hline \multicolumn{3}{|l|}{ SCLC } \\
\hline Limited & $168(50.4 \%)$ & \\
\hline Extensive & $165(59.6 \%)$ & \\
\hline \multicolumn{3}{|l|}{ NSCLC } \\
\hline 1 & $151(14.1 \%)$ & \\
\hline II & $140(13.1 \%)$ & \\
\hline III & 457 (42.7\%) & \\
\hline IV & $323(30.2 \%)$ & \\
\hline
\end{tabular}


A

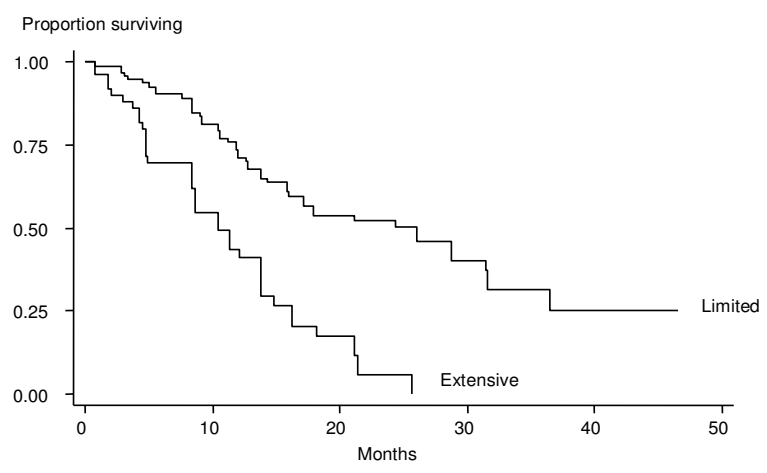

B

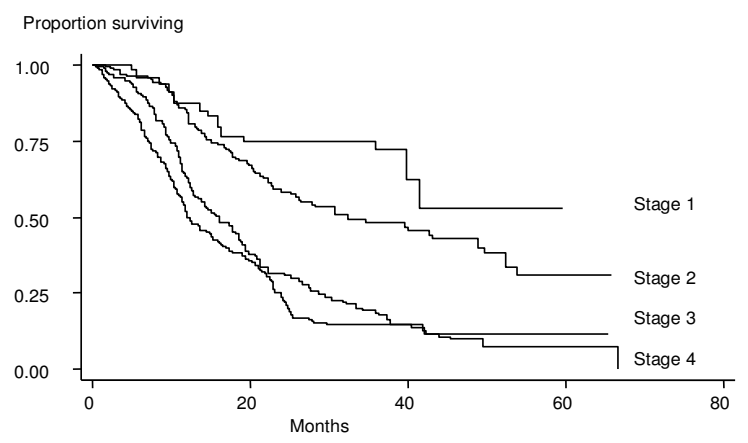

Figure 3

Survival from lung cancer in patients according to stage at presentation: A) Patients with SCLC, B) Patients with NSCLC. In both SCLC and NSLC survival was significantly better $(P<0.000 \mathrm{I})$ in patients presenting with early stage disease compared to those presenting with late stage disease in both Log rank tests of the difference in distribution of survival curves and in Cox-proportional hazard test, adjusting for age, sex, year of presentation and treatment with platinum-based chemotherapy. Statistical analyses performed using STATA version 8.0 (College Station, Tx, USA).

influence the aetiology in most cancers in the patient population as a whole.

To exploit the advances brought about by the human genome projects, future work in cancer genetics will be dependent upon the acquisition of large well-characterised cohorts of cancer cases. Here we have demonstrated that the centralisation of cancer services in the UK offers an opportunity to establish large, well-characterised cohorts by targeting collection to the largest centres. Moreover mobilising NCRN networks provides a means of delivering consistently the data and sample collection to complete genetic epidemiology studies, relating to the detection of main effects on the required scale.

Because ascertainment of cases through GELCAPS has been based on clinical centres specialising in the treatment of lung cancer a high proportion of cases have been diagnosed young. While this means cases are not fully representative of disease in the general population the distribution of age at diagnosis serves to empower GELCAPS for identifying disease-causing alleles by virtue of genetic enrichment.

Given that constitutional genotypes may well influence patient prognosis it is highly desirable that survivorship is not confounding influence on sample collection. As survival rates in patients recruited to GELCAPS were not significantly different to those documented in previously published audits of lung cancer in the UK there is no evidence that "healthy study participant" selection will have genetically biased ascertainment. For all participants, sex, ethnicity and age at sampling have been documented. The geographical area of birth and area of residence within the UK is known for all of the individuals and this information can be used to allow analyses stratified by region of residence, reducing any effects of population stratification. The possibility of population stratification leading to false inference of disease-genotype association can readily be addressed by adjusting for known region/ethnicity or by using information on unlinked genetic markers.

We acknowledge the potential problem of differential bias in genotyping samples accrued from different sources. Although the samples collected through GELCAPs have been ascertained from many clinical centres we have no evidence that this has affected sample quality as we have previously documented call rates of $99.8 \%$ in samples genotyped for 1,500 SNPs [32-35] and Quantile-Quantile plots of test association statistics provide no evidence for differential bias

The NCRN research networks are established within cancer care networks where access to partners is readily available and direct. They are not designed to collect samples from the general population so our choice of collecting samples from partners was a pragmatic one appropriate for the NCRN. Inevitably in studies such as GELCAPS a smaller number of samples from controls will be collected than from cases since in addition to lack of compliance many patients do not have a current partner. The sex of controls ascertained through initiatives such as GELCAPS will usually be of the opposite gender to cases, and con- 
trols are potentially over-matched with respect to many lifestyle risk factors. Theses limitations can be offset to a large degree by using samples collected from the healthy spouses/partners of one cancer as a source of controls for a different cancer. This is something we are currently pursuing with respect to a similar NRCN sponsored initiative the National Study of Colorectal Cancer Genetics (NSCCG)

Because of the difficulty of obtaining sufficiently detailed data on environmental exposure in studies such as GELCAPS, and because there are issues to do with comparability of exposure data from controls assembled from different studies, it is acknowledged that studies of environmental risk factors including gene-environment interaction will be limited in resources such as GELCAPS. The main value of collections such as GELCAPS will be in studies of genetic risk factors and gene-gene interactions; hypotheses regarding gene-environment interaction require alternative datasets, such as the European Prospective Investigation into Cancer and nutrition (EPIC) study [36], which are centred around population based-cohorts. Accepting such limitations our experience in developing GELCAPS serves to illustrate how large DNA databases for genetic analyses can rapidly be developed in the UK. At present we have only collected outcome data on around $20 \%$ of cases recruited to GELCAPS. By completing the collection of follow up data on all cases we shall be able to assemble a unique series for examining the influence of constitutional genotype on clinical outcome in the population setting.

\section{Conclusion}

Finally, it is noteworthy that the value of GELCAPS has been demonstrated in a recent GWAS of lung cancer we have conducted in which we have been able to robustly identify a susceptibility variant for the disease mapping to $15 q[37]$.

\section{Abbreviations}

GELCAPS: Genetic Lung Cancer Predisposition Study

\section{Compteting interests}

The authors declare that they have no competing interests.

\section{Authors' contributions}

TE and RSH were the principal investigators for the GELCAPS, devised the study. AM helped in study development and was responsible for database design, and management of study coordinators. All authors contributed to the paper.

\section{Availability \& requirements}

Cancer Research UK: http://www.cancerresearchuk.org
GELCAPS: $\quad \underline{\text { http://public.ukcrn.org.uk/Search/StudyDe }}$ tail.aspx?StudyID=781

National Cancer Research Network: http:// www.ncrn.org.uk

NHS Cancer Plan: http://www.dh.gov.uk/assetRoot/04/ 01/45/13/04014513.pdf

National Study of Colorectal Cancer Genetics: http:// www.icr.ac.uk/research/research sections/

cancer genetics/cancer genetics teams/

molecular and population genetics/nsccg/index.shtml

European Prospective Investigation into Cancer and Nutrition: http://epic.iarc.fr/

\section{Acknowledgements}

We are grateful to patients for their participation. This work was undertaken with support from, HEAL, Aventis, the NCRN and Cancer Research UK. Athena Matakidou was the recipient of a clinical research fellowship from the Allan J Lerner Fund.

\section{References}

I. Parkin DM, Bray F, Ferlay J, Pisani P: Global cancer statistics, 2002. CA Cancer J Clin 2005, 55(2):74- 108.

2. Matakidou A, Eisen T, Houlston RS: Systematic review of the relationship between family history and lung cancer risk. $\mathrm{Br}$ J Cancer 2005, 93(7):825-833.

3. Hwang SJ, Cheng LS, Lozano G, Amos Cl, Gu X, Strong LC: Lung cancer risk in germline p53 mutation carriers: association between an inherited cancer predisposition, cigarette smoking, and cancer risk. Hum Genet 2003, I I 3(3):238-243.

4. Draper GJ, Sanders BM, Kingston JE: Second primary neoplasms in patients with retinoblastoma. $\mathrm{Br} J$ Cancer 1986, 53(5):66I-67I.

5. Fletcher O, Easton D, Anderson K, Gilham C, Jay M, Peto J: Lifetime risks of common cancers among retinoblastoma survivors. Natl Cancer Inst 2004, 96(5):357-363.

6. Takemiya M, Shiraishi S, Teramoto T, Miki Y: Bloom's syndrome with porokeratosis of Mibelli and multiple cancers of the skin, lung and colon. Clin Genet 1987, 3 I (I):35-44.

7. Yamanaka A, Hirai T, Ohtake Y, Kitagawa M: Lung cancer associated with Werner's syndrome: a case report and review of the literature. Jpn J Clin Oncol 1997, 27(6):4I5-4I8.

8. Jonsson S, Thorsteinsdottir U, Gudbjartsson DF, Jonsson HH, Kristjansson K, Arnason S, Gudnason V, Isaksson HJ, Hallgrimsson J, Gulcher JR, Amundadottir LT, Kong A, Stefansson K: Familial risk of lung carcinoma in the Icelandic population. Jama 2004, 292(24):2977-2983.

9. Li X, Hemminki K: Inherited predisposition to early onset lung cancer according to histological type. Int J Cancer 2004, I I 2(3):45 I-457.

10. Osann KE: Lung cancer in women: the importance of smoking, family history of cancer, and medical history of respiratory disease. Cancer Res I99I, 5 I ( 1 8):4893-4897.

II. Shaw GL, Falk RT, Pickle LW, Mason TJ, Buffler PA: Lung cancer risk associated with cancer in relatives. J Clin Epidemiol 1991, 44(4-5):429-437.

12. Tsugane $S$, Watanabe $S$, Sugimura $H$, Arimoto $H$, Shimosato $Y$, Suemasu K: Smoking, occupation and family history in lung cancer patients under fifty years of age. Jpn J Clin Oncol 1987, I7(4):309-317.

13. Wu AH, Yu MC, Thomas DC, Pike MC, Henderson BE: Personal and family history of lung disease as risk factors for adenocarcinoma of the lung. Cancer Res 1988, 48(24 Pt I):7279-7284.

14. Risch N, Merikangas K: The future of genetic studies of complex human diseases. Science 1996, 273(5281):1516-1517. 
15. Botstein $D$, Risch N: Discovering genotypes underlying human phenotypes: past successes for mendelian disease, future approaches for complex disease. Nat Genet 2003, 33 Suppl:228-237.

16. Raimondi S, Paracchini V, Autrup H, Barros-Dios JM, Benhamou S, Boffetta P, Cote ML, Dialyna IA, Dolzan V, Filiberti R, Garte S, Hirvonen A, Husgafvel-Pursiainen K, Imyanitov EN, Kalina I, Kang D, Kiyohara C, Kohno T, Kremers P, Lan Q, London S, Povey AC, Rannug A, Reszka E, Risch A, Romkes M, Schneider J, Seow A, Shields PG, Sobti RC, Sorensen M, Spinola M, Spitz MR, Strange RC, Stucker I, Sugimura H, To-Figueras J, Tokudome S, Yang P, Yuan JM, Warholm M, Taioli E: Meta- and pooled analysis of GSTTI and lung cancer: a HuGE-GSEC review. Am J Epidemiol 2006, I64(I I): 1027-I042.

17. Carlsten C, Sagoo GS, Frodsham AJ, Burke W, Higgins JP: Glutathione S-Transferase MI (GSTMI) Polymorphisms and Lung Cancer: A Literature-based Systematic HuGE Review and Meta-Analysis. Am J Epidemiol 2008.

18. Kiyohara C, Yoshimasu K: Genetic polymorphisms in the nucleotide excision repair pathway and lung cancer risk: a metaanalysis. Int J Med Sci 2007, 4(2):59-7I.

19. Houlston RS: CYPIAI polymorphisms and lung cancer risk: a meta-analysis. Pharmacogenetics 2000, I0(2): I05-I I4.

20. Matakidou A, Eisen T, Houlston RS: TP53 polymorphisms and lung cancer risk: a systematic review and meta-analysis. Mutagenesis 2003, I 8(4):377-385.

21. Easton DF, Pooley KA, Dunning AM, Pharoah PD, Thompson D, Ballinger DG, Struewing JP, Morrison J, Field H, Luben R, Wareham N, Ahmed S, Healey CS, Bowman R, Meyer KB, Haiman CA, Kolonel LK, Henderson BE, Le Marchand L, Brennan P, Sangrajrang S, Gaborieau V, Odefrey F, Shen CY, Wu PE, Wang HC, Eccles D, Evans DG, Peto J, Fletcher O, Johnson N, Seal S, Stratton MR, Rahman N, ChenevixTrench G, Bojesen SE, Nordestgaard BG, Axelsson CK, Garcia-Closas M, Brinton L, Chanock S, Lissowska J, Peplonska B, Nevanlinna $H$, Fagerholm R, Eerola H, Kang D, Yoo KY, Noh DY, Ahn SH, Hunter DJ, Hankinson SE, Cox DG, Hall P, Wedren S, Liu J, Low YL, Bogdanova N, Schurmann P, Dork T, Tollenaar RA, Jacobi CE, Devilee P, Klijn JG, Sigurdson AJ, Doody MM, Alexander BH, Zhang J, Cox A, Brock IW, MacPherson G, Reed MW, Couch FJ, Goode EL, Olson JE, Meijers-Heijboer H, van den Ouweland A, Uitterlinden A, Rivadeneira F, Milne RL, Ribas G, Gonzalez-Neira A, Benitez J, Hopper JL, McCredie M, Southey M, Giles GG, Schroen C, Justenhoven C, Brauch H, Hamann U, Ko YD, Spurdle AB, Beesley J, Chen X, Mannermaa A, Kosma VM, Kataja V, Hartikainen J, Day NE, Cox DR, Ponder BA: Genome-wide association study identifies novel breast cancer susceptibility loci. Nature 2007, 447(7 | 48): 1087-1093.

22. Hunter DJ, Kraft P, Jacobs KB, Cox DG, Yeager M, Hankinson SE, Wacholder S, Wang Z, Welch R, Hutchinson A, Wang J, Yu K, Chatterjee N, Orr N, Willett WC, Colditz GA, Ziegler RG, Berg CD, Buys SS, McCarty CA, Feigelson HS, Calle EE, Thun MJ, Hayes RB, Tucker M, Gerhard DS, Fraumeni JF Jr., Hoover RN, Thomas G, Chanock SJ: A genome-wide association study identifies alleles in FGFR2 associated with risk of sporadic postmenopausal breast cancer. Nat Genet 2007, 39(7):870-874.

23. Gudmundsson J, Sulem P, Steinthorsdottir V, Bergthorsson JT, Thorleifsson G, Manolescu A, Rafnar T, Gudbjartsson D, Agnarsson BA, Baker A, Sigurdsson A, Benediktsdottir KR, Jakobsdottir M, Blondal T, Stacey SN, Helgason A, Gunnarsdottir S, Olafsdottir A, Kristinsson KT, Birgisdottir B, Ghosh S, Thorlacius S, Magnusdottir D, Stefansdottir G, Kristjansson K, Bagger Y, Wilensky RL, Reilly MP, Morris AD, Kimber CH, Adeyemo A, Chen Y, Zhou J, So WY, Tong PC, Ng MC, Hansen T, Andersen G, Borch-Johnsen K, Jorgensen T, Tres A, Fuertes F, Ruiz-Echarri M, Asin L, Saez B, van Boven E, Klaver S, Swinkels DW, Aben KK, Graif T, Cashy J, Suarez BK, van Vierssen Trip O, Frigge ML, Ober C, Hofker MH, Wijmenga C, Christiansen C, Rader DJ, Palmer CN, Rotimi C, Chan JC, Pedersen O, Sigurdsson G, Benediktsson R, Jonsson E, Einarsson GV, Mayordomo Jl, Catalona WJ, Kiemeney LA, Barkardottir RB, Gulcher JR, Thorsteinsdottir U, Kong $A$, Stefansson K: Two variants on chromosome 17 confer prostate cancer risk, and the one in TCF2 protects against type 2 diabetes. Nat Genet 2007, 39(8):977-983.

24. Eeles RA, Kote-Jarai Z, Giles GG, Olama AA, Guy M, Jugurnauth SK, Mulholland S, Leongamornlert DA, Edwards SM, Morrison J, Field HI, Southey MC, Severi G, Donovan JL, Hamdy FC, Dearnaley DP, Muir KR, Smith C, Bagnato M, Ardern-Jones AT, Hall AL, O'Brien LT, Gehr-Swain BN, Wilkinson RA, Cox A, Lewis S, Brown PM, Jhavar
SG, Tymrakiewicz M, Lophatananon A, Bryant SL, Horwich A, Huddart RA, Khoo VS, Parker CC, Woodhouse CJ, Thompson A, Christmas T, Ogden C, Fisher C, Jamieson C, Cooper CS, English DR, Hopper JL, Neal DE, Easton DF: Multiple newly identified loci associated with prostate cancer susceptibility. Nat Genet 2008. 25. Amundadottir LT, Sulem P, Gudmundsson J, Helgason A, Baker A, Agnarsson BA, Sigurdsson A, Benediktsdottir KR, Cazier JB, Sainz J, Jakobsdottir M, Kostic J, Magnusdottir DN, Ghosh S, Agnarsson K, Birgisdottir B, Le Roux L, Olafsdottir A, Blondal T, Andresdottir M, Gretarsdottir OS, Bergthorsson JT, Gudbjartsson D, Gylfason A, Thorleifsson G, Manolescu A, Kristjansson K, Geirsson G, Isaksson H, Douglas J, Johansson JE, Balter K, Wiklund F, Montie JE, Yu X, Suarez BK, Ober C, Cooney KA, Gronberg H, Catalona WJ, Einarsson GV, Barkardottir RB, Gulcher JR, Kong A, Thorsteinsdottir U, Stefansson $\mathrm{K}$ : A common variant associated with prostate cancer in European and African populations. Nat Genet 2006, 38(6):652-658.

26. Haiman CA, Patterson N, Freedman ML, Myers SR, Pike MC, Waliszewska A, Neubauer J, Tandon A, Schirmer C, McDonald GJ, Greenway SC, Stram DO, Le Marchand L, Kolonel LN, Frasco M, Wong D, Pooler LC, Ardlie K, Oakley-Girvan I, Whittemore AS, Cooney KA, John EM, Ingles SA, Altshuler D, Henderson BE, Reich D: Multiple regions within $8 \mathrm{q} 24$ independently affect risk for prostate cancer. Nat Genet 2007, 39(5):638-644.

27. Haiman CA, Le Marchand L, Yamamato J, Stram DO, Sheng X, Kolonel $\mathrm{LN}, \mathrm{Wu} A \mathrm{AH}$, Reich D, Henderson BE: A common genetic risk factor for colorectal and prostate cancer. Nat Genet 2007, 39(8):954-956.

28. Jaeger E, Webb E, Howarth K, Carvajal-Carmona L, Rowan A, Broderick P, Walther A, Spain S, Pittman A, Kemp Z, Sullivan K, Heinimann K, Lubbe S, Domingo E, Barclay E, Martin L, Gorman M, Chandler I, Vijayakrishnan J, Wood W, Papaemmanuil E, Penegar S, Qureshi M, Farrington S, Tenesa A, Cazier JB, Kerr D, Gray R, Peto J, Dunlop M, Campbell H, Thomas H, Houlston R, Tomlinson I: Common genetic variants at the CRACI (HMPS) locus on chromosome I 5q I 3.3 influence colorectal cancer risk. Nat Genet 2008, 40(I):26-28.

29. Broderick P, Carvajal-Carmona L, Pittman AM, Webb E, Howarth K, Rowan A, Lubbe S, Spain S, Sullivan K, Fielding S, Jaeger E, Vijayakrishnan J, Kemp Z, Gorman M, Chandler I, Papaemmanuil E, Penegar S, Wood W, Sellick G, Qureshi M, Teixeira A, Domingo E, Barclay E, Martin L, Sieber O, Kerr D, Gray R, Peto J, Cazier JB, Tomlinson I, Houlston RS: A genome-wide association study shows that common alleles of SMAD7 influence colorectal cancer risk. Nat Genet 2007, 39(II): I3I5-1317.

30. Tomlinson I, Webb E, Carvajal-Carmona L, Broderick P, Kemp Z, Spain S, Penegar S, Chandler I, Gorman M, Wood W, Barclay E, Lubbe S, Martin L, Sellick G, Jaeger E, Hubner R, Wild R, Rowan A, Fielding S, Howarth K, Silver A, Atkin W, Muir K, Logan R, Kerr D, Johnstone E, Sieber O, Gray R, Thomas H, Peto J, Cazier JB, Houlston R: A genome-wide association scan of tag SNPs identifies a susceptibility variant for colorectal cancer at 8q24.2I. Nat Genet 2007, 39(8):984-988.

3I. Zanke BW, Greenwood CM, Rangrej J, Kustra R, Tenesa A, Farrington SM, Prendergast J, Olschwang S, Chiang T, Crowdy E, Ferretti $V$, Laflamme P, Sundararajan S, Roumy S, Olivier JF, Robidoux F, Sladek R, Montpetit A, Campbell P, Bezieau S, O'Shea AM, Zogopoulos G, Cotterchio M, Newcomb P, McLaughlin J, Younghusband B, Green R, Green J, Porteous ME, Campbell H, Blanche H, Sahbatou M, Tubacher E, Bonaiti-Pellie C, Buecher B, Riboli E, Kury S, Chanock SJ, Potter J, Thomas G, Gallinger S, Hudson TJ, Dunlop MG: Genomewide association scan identifies a colorectal cancer susceptibility locus on chromosome 8q24. Nat Genet 2007, 39(8):989-994.

32. Rudd MF, Webb EL, Matakidou A, Sellick GS, Williams RD, Bridle H, Eisen T, Houlston RS: Variants in the GH-IGF axis confer susceptibility to lung cancer. Genome Research 2006, 16(6):693-70I.

33. Johnson N, Fletcher O, Palles C, Rudd M, Webb E, Sellick G, Dos Santos Silva I, McCormack V, Gibson L, Fraser A, Leonard A, Gilham C, Tavtigian SV, Ashworth A, Houlston R, Peto J: Counting potentially functional variants in BRCAI, BRCA2 and ATM predicts breast cancer susceptibility. Hum Mol Genet 2007, 16(9): 105|-1057.

34. Webb EL, Rudd MF, Sellick GS, El Galta R, Bethke L, Wood W, Fletcher O, Penegar S, Withey L, Qureshi M, Johnson N, Tomlinson I, Gray R, Peto J, Houlston RS: Search for low penetrance alleles 
for colorectal cancer through a scan of 1467 non-synonymous SNPs in 2575 cases and 2707 controls with validation by kin-cohort analysis of 14704 first-degree relatives. Hum Mol Genet 2006, 15(21):3263-327I.

35. Rudd MF, Sellick GS, Webb EL, Catovsky D, Houlston RS: Variants in the ATM-BRCA2-CHEK2 axis predispose to chronic lymphocytic leukemia. Blood 2006, 108(2):638-644.

36. Riboli E, Hunt KJ, Slimani N, Ferrari P, Norat T, Fahey M, Charrondiere UR, Hemon B, Casagrande C, Vignat J, Overvad K, Tjonneland A, Clavel-Chapelon F, Thiebaut A, Wahrendorf J, Boeing $\mathrm{H}$, Trichopoulos D, Trichopoulou A, Vineis P, Palli D, Bueno-De-Mesquita HB, Peeters PH, Lund E, Engeset D, Gonzalez CA, Barricarte A, Berglund G, Hallmans G, Day NE, Key TJ, Kaaks R, Saracci R: European Prospective Investigation into Cancer and Nutrition (EPIC): study populations and data collection. Public Health Nutr 2002, 5(6B): IIII3-II 24.

37. Amos Cl, Wu X, Broderick P, Gorlov G, Gu J, Eisen T, Dong D, Zhang D, Gu X, Vijayakrishnan J, Sullivan K, Matakidou A, Wang Y, Mills G, Kimberly Doheny K, Tsai YY, Shete S, Spitz M, Houlston RS: A genome-wide association scan of tag SNPs identifies a susceptibility locus for lung cancer at 15q25.I. Nat Genet 2008, 40(5):616-622.

\section{Pre-publication history}

The pre-publication history for this paper can be accessed here:

http://www.biomedcentral.com/1471-2407/8/244/pre pub

Publish with Bio Med Central and every scientist can read your work free of charge

"BioMed Central will be the most significant development for disseminating the results of biomedical research in our lifetime. "

Sir Paul Nurse, Cancer Research UK

Your research papers will be:

- available free of charge to the entire biomedical community

- peer reviewed and published immediately upon acceptance

- cited in PubMed and archived on PubMed Central

- yours - you keep the copyright

Submit your manuscript here:

http://www.biomedcentral.com/info/publishing_adv.asp 